\title{
The elusive sustainable development of small tropical islands
}

\begin{abstract}
The notion of sustainable development is one of the most popular concepts of our time. However, it remains controversial and quite problematic, especially for small islands and their communities. These challenges arise in relation to the limited scope of resources which can be used for development, and the difficulty of defining the needs of future generations.

Looking at the history of many island jurisdictions, one is confronted with a picture of substantial economic evolution. Island communities have rarely, if ever, been able to foresee or plan their future; frequently, the situation has turned out to be very different from any previously envisaged scenarios. This should not be surprising, since small island destinies are often determined by external variables, over which they have little, if any, control. These variables include colonization, competition over scarce territories, improvements in transportation technologies, the information revolution and natural disasters. Thus, the very idea of sustainable development with respect to small islands is nothing but a charming slogan, an entertaining fiction rather than a reachable target. Of course, islands and their communities can take 'green' initiatives that are more environmentally friendly; they cannot, however, achieve a state of sustainable development, except with a serious deterioration in the quality of life and off-island connectivity (by air or sea) of their residents.
\end{abstract}

Keywords

Sustainable development $\bullet$ islands $\bullet$ tropical islands $\bullet$ Oceania

(C) University of Warsaw - Faculty of Geography and Regional Studies

\section{Introduction}

The aim of this paper is to show that the notion of 'sustainable development' is a very popular slogan, but does not express a real possibility for development, especially for small islands. In these cases, sustainable development is an elusive utopia, a simply unrealisable myth.

The notion of sustainable development is currently one of the world's trendiest methods of applying geography and social studies. It has been extensively analysed, expanded, and transformed (Hopwood, Meller \& O'Brien 2005).

It is relatively easy to define the ecological dimension of sustainable development, as H.E. Daly, among others, shows: 'For the management of renewable resources there are two obvious principles of sustainable development: (1) that harvest rates should equal regeneration rates (sustained yield); (2) that waste emission rates should equal the natural assimilative capacities of the ecosystems into which the wastes are emitted. For non-renewable resources, it is possible for exploitation in a quasi-sustainable manner by limiting their rate of depletion to the rate of creation of renewable substitutes. In addition to assuring the renewable substitution of non-renewable resources, the continued existence of complementary natural capital must also be assured' (Daly 1990).

However, the environmental dimension is not the only side to sustainable development. The significance of the mutual relationships occurring in this process between the environment,

\author{
Maciej Jędrusik \\ Department of World Regional Geography \\ Faculty of Geography and Regional Studies \\ University of Warsaw \\ e-mail: maciusik1@uw.edu.pl \\ Received: 10 June 2014 \\ Accepted: 28 July 2014
}

economy, and society is frequently and justly highlighted (Giddings, Hopwood \& O'Brien 2002). The designs or dreams of sustainable development cannot exclude any of these elements.

For over 25 years, representatives of various sciences - from environmental science, to sociology, economics, and law - have been contributing to discussions on sustainable development. This has produced an expansion, but also chaos, in the understanding of the term. The genesis and initial principles have often been forgotten. Redclift (2005) wrote of sustainable development: 'It argues that the superficial consensus that has characterized much of the early debate has given way to a series of parallel but distinct discourses around sustainability. The underlying assumptions behind much of the discussion are assessed (...) after the first Earth Summit to focus on rights, rather than needs, as the principal line of enquiry. This analytical attention to rights is linked to the neo-liberal economic agendas of the 1990s, and the growth of interest in congruent areas, including human security and the environment, social capital, critical natural capital and intellectual property rights'.

There is no shortage of definitions for sustainable development; on the contrary, there are too many - it seems as if every researcher has had the ambition of creating or expanding the description. But regardless of the evolution of the concept, it is important to remember the Brundtland Commission's definition proposed in 1987, the idea of rational utilisation of 
natural resources with consideration for future generations and their ability to utilise a similar potential. However, the author herself noted that we do not know the future or our future needs (Brundtland 1987).

Therefore, the idea of sustainable development has the potential to become popular, but it is debatable for many reasons. How do you project the needs of future generations? How do you resist the temptation of excessive exploitation? What is the limit of this 'excess'? These are only some of the many questions that can be asked in this context.

\section{Sustainable development of islands?}

These questions are common to all territories and all populations. Since such doubts appear in relation to large territories with large resources and controllable demographic processes, they will naturally be magnified in the case of insular communities with limited resources. We can assume that the level of the problem rises inversely to the size of an island. The smaller the island, the smaller the potential and the ability to differentiate developmental strategies.

Therefore, the following contemplations on the possibilities of sustainable development will refer to smaller insular territories, where dependencies are more clearly expressed.

Returning to the aforementioned mutual relationships occurring in this process between the environment, economy and society, we must note that all three elements present features which are particularly limiting of development on islands. Natural environments are surrounded by a natural barrier and are also susceptible to external and internal stimuli. The economy is small, not very flexible and not very diverse. Demographic pressure or under-population and their effects bring problems which are much more intense on islands than on continental land. Therefore, all three pillars of sustainable development impose limitations.

The aforementioned limitations are immanent features of islands. During different periods, the limiting roles may change, for example intensifying with demographic pressure or weakening with the inflow of new technologies. However, they never disappear.

The economic history of islands allows the stages of their development to be distinguished, depending on the dominant features suggesting the economic specialisation. The evolution of territories located in various regions is similar, although the pace of transformation indicates regional variety. The diagram of such evolution on tropical islands is presented in Table 1.

A just question arises: in the contemporary sense, has sustainable development appeared in some place and time on insular territories?

\section{a. Native economy}

It seems that the earliest period, that associated with native economy, came the closest. The economies of the islands were relatively closed, with low levels of trade, which took place between neighbours with similar civil traits. Subsistence agriculture held the main position of significance, which was complemented by limited exploitation of the coastal bodies of water. At that time, the essence of the insular economies was the need to satisfy the basic demands of the locals: food, and, to various degrees, 'luxuries' - clothing, decorations (e.g. coconut shells, seashells, fabrics from banana fibres), as well as the weapons necessary for wars with neighbours, which were common in those times. It was the need to possess 'luxury' and, from the viewpoint of the islanders, exotic goods that lay at the foundation of the development of inter-island trade, the range of which covered large oceanic areas.

Sometimes, this relative harmony was interrupted by wars with neighbours, natural cataclysms, uncontrolled population growth and religious or ideological dogmas (as in the case of Rapa Nui). However, in general, the balance in the exploitation of natural resources was preserved and the economic transformations took place very slowly. This trait was common to all regions.

This unnamed, probably unconscious sustainable development lasted as long as the isolation of the islands from external influences originating from the colonial metropolises. Therefore, perhaps sustainable development is possible only in a closed system, isolated from external influences.

The end of this balance was initiated by so-called 'white contact'. This phenomenon is described in an interesting manner by Jan Stanislaw Kubary, the $19^{\text {th }}$ century Polish researcher of Micronesia and Polynesia, which was the last region to be exposed to the trend. Describing Samoa (circa 1870), he

Table 1. An outline of economic changes on tropical islands since the 15th century

\begin{tabular}{|c|c|c|c|c|c|}
\hline \multirow[b]{2}{*}{ Century } & \multicolumn{2}{|c|}{ Atlantic Ocean } & \multicolumn{2}{|c|}{ Indian Ocean } & \multirow[b]{2}{*}{ Pacific Ocean } \\
\hline & West & East & $\begin{array}{l}\text { Mauritius, Reunion, } \\
\text { Seychelles }\end{array}$ & Others & \\
\hline 15th c. & AF & $A F P$ & - & $A F$ & AF \\
\hline 16th $\mathrm{c}$. & AF & $\mathbf{P}$ & - & AF & A F \\
\hline 17th c. & AFP & $\mathbf{P}$ & $\mathbf{P}$ & $A F$ & AF \\
\hline 18th $\mathrm{c}$. & $\mathbf{P}$ & $\mathbf{P}$ & $\mathbf{P}$ & AF & AF \\
\hline 19th $\mathrm{c}$. & $\mathbf{P}$ & P T & $\mathbf{P}$ & AF & AF P \\
\hline $1900-1950$ & P T & P T & $\mathbf{P}$ & $\mathbf{P}$ & $P \quad N$ \\
\hline $1960-1970$ & P T & $P T$ & $\mathbf{P}$ & $\mathbf{P}$ & PT N \\
\hline $1970-1980$ & TN & P T & P T & P T & P T N \\
\hline $1980-1990$ & $T N$ & P T & P T & P T & TN \\
\hline $1990-2000$ & $T N$ & P T & P T & $T$ & TN \\
\hline $2000-$ & $T N$ & $T$ & $P T$ & $T$ & $T N$ \\
\hline
\end{tabular}

A - agriculture; F - fishery, $P$ - plantations, $T$ - tourism, $N$ - new economy (MIRAB, offshore zones, 'tax havens' etc.) Note: From '„Emerging Islands”- a new role of tropical islands in the world' (Jędrusik 2006) 
MISCELLANEA GEOGRAPHICA - REGIONAL STUDIES ON DEVELOPMENT

Vol. $18 \cdot$ No. $3 \cdot 2014 \cdot$ pp. 26-30 • ISSN: 2084-6118 • DOI: 10.2478/mgrsd-2014-0026

Table 2. Tourist traffic vs. affluence of insular territories (ca. 2000)

\begin{tabular}{|c|c|c|c|}
\hline $\begin{array}{l}\text { Territory(GDP per capita) } \\
\text { Tourist traffic } \\
\text { ITM }(\mathrm{Nt} / \mathrm{P} * 100)\end{array}$ & $\begin{array}{c}\text { Poor } \\
<3000 \text { USD }\end{array}$ & $\begin{array}{c}\text { Medium } \\
3000-10000 \text { USD }\end{array}$ & $\begin{array}{c}\text { Rich } \\
>10000 \text { USD }\end{array}$ \\
\hline $\begin{array}{l}\text { Small } \\
<100\end{array}$ & $\begin{array}{c}\text { St Vincent, Socotra, } \\
\text { Comoros, Mayotte, } \\
\text { Zanzibar, Cape Verde, } \\
\text { Sao Tome, Solomon I., } \\
\text { Vanuatu, Marshall I., } \\
\text { Tuvalu, Tonga, Kiribati, } \\
\text { FSM }\end{array}$ & $\begin{array}{l}\text { Jamaica, Dominica, Trinidad } \\
\text { \& Tobago, Reunion, Niue, } \\
\text { Fiji, Samoa, American } \\
\text { Samoa }\end{array}$ & $\begin{array}{l}\text { Puerto Rico, Christmas I., } \\
\text { Cocos I., Mauritius, New } \\
\text { Caledonia }\end{array}$ \\
\hline $\begin{array}{l}\text { Medium } \\
101-500\end{array}$ & & $\begin{array}{l}\text { Montserrat, Guadeloupe, } \\
\text { St Kitts, Grenada, St } \\
\text { Lucia, Anguilla, Maldives, } \\
\text { Seychelles, Cook I. , Palau, } \\
\text { French Polynesia }\end{array}$ & $\begin{array}{c}\text { Curacao, Martinique, } \\
\text { Antigua \& Barbuda, Bonaire, } \\
\text { Barbados, Virgin I., Hawaii }\end{array}$ \\
\hline $\begin{array}{c}\text { Big } \\
>500\end{array}$ & & Turks \& Caicos, Phuket & $\begin{array}{c}\text { Bahamas, Saba, St } \\
\text { Eustatius, St Marteen, Aruba, } \\
\text { Cayman I., British Virgin I., } \\
\text { Canary I., Guam, Norfolk, } \\
\text { Northern Marianas }\end{array}$ \\
\hline
\end{tabular}

Note: From '„Emerging Islands” - a new role of tropical islands in the world' (Jędrusik 2006)

wrote: 'This country is not subject to any epidemic diseases. All of the islands, crossed by rivers and streams falling from the mountains, form one park, a bunch of bouquets floating on the ocean. The rich, tropical soil bears everything in abundance. The coconut palms not only feed the locals, but are also the main factors of export trade. The cotton is as beautiful as can be. The sugarcanes grow almost wildly. The attempts to cultivate coffee and tea also brought encouraging results. Taro (Arum genus), yams (Dioscorea alata), breadfruit (Artocarpus incisa), screw pines, pineapples, oranges, lemons, watermelons, bananas, melon trees (Carica papaya) and many others bear in abundance. They feed the natives, suffice for the foreigners and their ships, and still rot uneaten in the excess of abundance.' (eds Jędrusik \& Jackowska 1997 ref: Kubary 1873, p. 158). How far is this from the contemporary ideas of a rational economy or 'sustainable development'?

\section{b. Colonial expansion}

However, this image was disturbed by colonial expansion, as commented on below by the same researcher: 'Politically, the Navigator Islands are independent and have not been annexed by any European government, to the exceptional pain of the local white residents, who are ever the lovers of freedom and would like to turn Samoa into New Caledonia, Sydney or Tahiti, and make themselves the great administrators of the new annex (...). Anyway, the Europeans themselves maintain the residents in constant fear and caution. The English, the missionaries in particular, were the first to settle here and were held in check by the French missionaries. Therefore, they have taught the Samoans love for their peers in the following way: "Do not sell land to the French for them to build churches and schools, because they want to rob you." As the French settled, they play tit for tat. Both are defamed by the Americans observing from the sidelines - and all become the victims of the Germans. Therefore, this is a constant cross-fire of excitement and intrigue.' (eds Jędrusik \& Jackowska 1997 ref: Kubary 1873, pp. 159-160).

So 'white contact' heralded the end of the first version of sustainable development in the islands and prevented such development. It is clear that, since that time, contacts between the islands (their communities and economies) and the outside world have not disappeared, but evolved. This is a product of the aforementioned economic transformations.

Do any of the options presented in Table 1 show properties of sustainable development? During the times of colonial economy, the resources of the islands were robbed by plantation agriculture, forest felling and excessive fishery. During the postcolonial times, the resources of most territories were so depleted and the external demand for insular goods so limited that it was not possible to avoid the accelerating transformations of the economic structure. Only a few territories were able to preserve the mirage of stabilisation, such as Nauru, which was discussed by J.C. Roux: 'Without its phosphorites, which provided it with exceptional wealth, Nauru would be a lost island, home to the miserable existence of a small population.' (Roux 1995, p. 380). These words turned out to be prophetic following the year 2000 , with the end of extraction. This is a great example of 'unsustainable development'.

\section{c. Post-colonial economic transformation}

The only thing left to explore on the islands was the possibility for new foundations of economic stabilisation and development. This is the origin of the new economy (MIRAB, offshore zones, 'tax havens' etc.), providing the islands with the almost omnipresent drive towards the development of tourism, which does not much depend on potential.

However, can these economic solutions pass as properties of sustainable development? Some of the new solutions are neutral to the local resources. The sex-telephones and data transmission or sales of internet domains (such as on Tuvalu, Tonga, Niue, the Solomon Islands and Vanuatu), sale of rights to use airspace, including positions on geostationary orbits (Tonga), virtual banks (Nauru, the Cook Islands), and internet gambling (Micronesia, Fiji, New Caledonia, the Solomon Islands, Vanuatu, the Cook Islands) do not bring harm to the islands' natural resources. However, it is difficult to count on sustainable development on the basis of such irregular phenomena, and the material benefits are also limited. 
What about tourism? Expanding on the idea of G.H. Bruntland, J. Swarbrooke (1999) attempted to define sustainable tourism as forms of tourism combining the satisfaction of the demands of contemporary tourists, tourism companies, and local communities, without limiting the abilities of satisfying the demands of future generations. This elegant definition perfectly combines the benefits of all interested parties, but the possibility of its implementation is small.

The numerous other existent definitions of sustainable tourism often contradict each other. There is no consensus on this matter, as stressed by Butler (1999), and Gössling, Hall \& Weaver (2009), as well as other researchers of this phenomenon. As Butler notes, perhaps the factor constituting the essence of sustainable tourism should be 'small scale'.

However, the contemporary drive of insular territories towards tourism development leaves no doubts concerning the scale of the ventures. The natural environments - the natural resources - are processed on a grand scale, which is often irreversible. The standard example is the Maldives, which have created an artificial tourist space, isolated from the native space. However, both areas have been significantly transformed - the tourism area underwent ecological changes (construction of a marina, territorial expansion, creation of beaches, replacement of plants, construction of desalinising plants and other technical installations) and social transformations (e.g. lack of natives). The 'native' space has become the collector of the waste left behind by the tourist activity (Jędrusik 2003). The multiple examples of tourist development transforming nature can be found on all oceans, from the Caribbean to Micronesia and Polynesia. Even on a small scale, tourism significantly transforms social spaces, provoking new conflicts. A contemporary example comes from Reunion: "overcrowding is the cause of numerous conflicts of use. Conflict has arisen from the closing of "fishermen's paths" by residents that prevents access to the sea along their properties. There is also conflict between beach users and owners of "oceanside" properties (hotels and residences) who privatize the Public Maritime Domain by encroaching on the beaches. Finally, conflict occurs between clubbers and those residing near places of entertainment, who complain about the noise and disturbances caused by nocturnal activities' (Jauze 2013, pp.6-7).

The immediate economic benefits are visible. In general, there is no poverty in territories with an average or high intensity of tourist traffic (Table 2). Growing tourism, which entails an increasing number of tourist installations, contradicts the 'small scale' of the ventures required by sustainable tourism. Thus, the development of tourism denies the idea of sustainable development.

\section{Conclusions}

If not tourism (since it is not sustainable), if not 'new economy' (since it is based on virtual or unstable sources), if not plantation agriculture (since it naturally burdens the environment and depletes the resources), then what could drive such sustainable development on islands? The only emerging answer is NOTHING. It can be established that sustainable development is not possible on insular territories. Instead, this slogan expresses a dream. It inspires fantasists to search for a paradise as mythical as the Renaissance Arcadia.

Of course, management should be conducted in harmony with nature, preserving resources, but this is not enough to produce sustainable development in the sense suggested by G.H. Brundtland.

In 1990, a piece of work entitled 'Sustainable development and environmental management of small islands' was published under the Man and Biosphere programme. One of its co-authors, P. G. d'Ayala, wrote the following in the introduction: 'Small islands provide a special case in development, largely due to special characteristics of their natural resources, economies and, in many cases, their cultures. Ecologically and economically sustainable development options are few (..), provision of utilities and public services is difficult and costly, human resources are scarce (...), and, especially on the smallest islands (...) little economic development has occurred without outside intervention. The trends in economic development of many small islands have been characterized as disappointing (...), and selfsufficiency may be hardly possible' (eds Beller, d'Ayala \& Hein 1990, p. 4).

This was written almost 25 years ago. The observations referred to above remain valid. There is no way to find insular territories which are developing in compliance with the idea of sustainable development. So what is the point of probing this idea? Is this about excuses for more conference presentations or published papers?

As much as it is difficult to suggest methods of sustainable development in these cases, it is easy to caution against unsustainable development. Perhaps the most important objective of sustainable development reminders is to caution against playing with nature and its resources in the exceptionally sensitive area of small islands, which are in dire need of responsible development.

\section{References}

Beller, W, d'Ayala, P \& Hein, P (eds.) 1990, Sustainable development and environmental management of small islands, UNESCO, Parthenon Publishing Group, Paris, Carnforth, Park Ridge.

Brundtland, GH 1987, Our common future. World Commission on Environment and Development, Oxford University Press, Oxford.

Butler, RW 1999, 'Sustainable tourism: a state of the art review', Tourism Geographies, vol. 1, no. 1, pp. 7-25.

Daly, HE 1990, 'Toward some operational principles of sustainable development', Ecological Economics, vol. 2, no. 1, pp. 1-6.

Giddings, B, Hopwood, B \& O'Brien, G 2002, 'Environment, economy and society: fitting them together into sustainable development', Sustainable Development, vol. 10, pp. 187-196 DOI: 10.1002/sd.199.

Gössling, S, Hall, MC \& Weaver, DB 2009, Sustainable tourism futures: perspectives on systems. Restructuring and innovations, Routledge, New York.
Hopwood, B, Mellor, M \& O’Brien, G 2005, 'Sustainable development. Mapping different approaches', Sustainable Development, vol. 13, pp. 38-52. DOI: 10.1002/sd.244.

Jauze, JM 2013, 'Highs and lows of the resortification of the SaintPaul coast (Reunion Island)', Miscellanea Geographica Regional Studies on Development, vol. 17, no. 1, pp. 5-14. DOI: 10.2478/v10288-012-0029-y.

Jędrusik, M \& Jackowska, M (eds) 1997, Wyspy ciepłych mórz. Jana Stanisława Kubarego notaty z podróży po Mikronezji, WGSR UW, Warszawa.

Jędrusik, M 2003, 'Les îles avec et sans passé. Le cas de South Ari Atoll (lles Maldives)' in Patrimoines et développement dans les pays tropicaux, eds P Cosaert \& F Bart, DYMSET, Pessac, pp. 641-648.

Jędrusik, M 2006, "Emerging Islands" - a new role of tropical islands in the world', Asia\&Pacific Studies, vol. 3, pp.5174.

Kubary, JS 1873, 'Obrazki z Wysp Żeglarskich na Oceanie 
MISCELLANEA GEOGRAPHICA - REGIONAL STUDIES ON DEVELOPMENT

Vol. 18 • No. 3 • 2014 • pp. 26-30 • ISSN: 2084-6118 • DOI: 10.2478/mgrsd-2014-0026

Wielkim zebrane w 1870 roku przez Jana Kubarego', Tygodnik Ilustrowany, XII, pp. 288-294.

Redclift, M 2005, 'Sustainable development (1987-2005): an oxymoron comes of age', Sustainable Development, vol. 13, pp. 212-227. DOI: 10.1002/sd.281.

Roux, JC 1995, Wallis et Futuna: espaces et temps recomposes. Chroniques d'une microinsularité, CRET, Bordeaux-Talence. Swarbrooke, J 1999, Sustainable tourism management, CABI Publishing, New York. 